\title{
In the name of human rights: the problematics of EU ethical foreign policy in Africa and elsewhere ${ }^{1}$
}

\author{
Olivia Umurerwa Rutazibwa \\ Department of Political Sciences, Ghent University
}

\begin{abstract}
This doctoral research project explores avenues to research ethically defined foreign policy differently, i.e. in ways that more systematically account for its counterproductive elements. Building on the specific case of the European Union's foreign policy in sub-Saharan Africa, embodied by the 2000 Cotonou Agreement and the 2007 Joint Africa-EU Strategy, through four papers and one books review, the study firstly develops the Ethical Intervener Europe analytical framework to account for the embedded problematics in the EU's ethical foreign policy. Secondly, through an eclectic theoretical approach, the study seeks to theoretically pin-point some alternatives to think about ethical foreign policy and finally, looks to concretize it through its application on the case of relative autonomous peace- and state-building in Somaliland. This research report briefly introduces the different findings and addresses the need for further research in view of a decolonial approach to the study of ethical foreign policy in a context of structural inequality.
\end{abstract}

Key words: ethical foreign policy, (humanitarian) interventions, EU, sub-Saharan Africa, Somaliland, decoloniality, democratization, state-building

\section{The study of the problematics of ethical foreign policy as a decolonizing strategy}

In the last decades, issues of globalization have taken the centre stage in the social sciences, not in the least in the study of International Relations (IR). Lately we see that both in research and public discourse, the focus is moving towards the so-called emerging economies and the shifting powers on the global scene, away from a western-centric world order as we know it.

In the social sciences, this move away from a western-centric understanding of reality has already for several decades been embodied by the heterogeneous post-colonial schools of thought, most famously through the works of Edward Said and Franz Fanon. At first predominantly developed in literary, cultural and anthropological studies, recently post-colonial insights are finding ground in political sciences and IR. (e.g. Kapoor 2008, 
Ferguson I990, 2007, Baaz 2005, Doty I996, Muppidi 2012) Post-colonial approaches to IR denounce the silencing of non-western peoples and their experiences and seek to rectify what are seen as myths and myopia in mainstream IR. Examples of these myths range from the origins of wealth accumulation in the West, to the striking absence of issues of racism (Vitalis 2000, Henderson 2007) and atrocities (Muppidi 2012) in the mainstream IR knowledge production.

In the last few years there has been a call to go beyond the level of denunciation to pro-active decolonizing strategies in the social sciences, including in IR. (e.g. Sabaratnam 20II, Jones 2006, Seth 2013, Scott 1999) Meera Sabaratnam makes a typology of six decolonizing strategies in the existing literature, here I conflate them to the following three. Firstly there is the need to demythologize by reframing existing arguments and scholarship to add to the rectification of the western-centric bias in mainstream knowledgeproduction about the world. Secondly the desilence strategy seeks to insert the non-western and marginalized experiences within the west as subjects of the knowledge production and theory formation. A third strategy is about decoloniality: going beyond the mere postcolonial denunciation of western-centric myths and silencing practices by actively putting the postcolonial insights at the service of the search for anti-colonial alternatives.

In this doctoral research, an attempt was made to contribute to this call to decolonize by reframing the arguments in contemporary debates on ethical foreign policy. Whereas dominant accounts look for ways to be more involved in the non-west, in my research I explored the salience of ethical retreat. Inspired by African, American and European radical democratic thought and the case of Somaliland, I explored the ideas of politics of difference and autonomous recovery as enactments of ethical retreat.

The bulk of the scholarship on ethical foreign policy issues such as democracy promotion, development, humanitarian interventions and peace- and statebuilding, focus on ways to do more and better in order to contribute to the well-being of peoples abroad. (Arts 2004, Smith 200I, 2005, Carbone 2008, Paris \& Sisk 2009) Few study the underlying assumptions that guide contemporary ethical involvement, to explain its failure. (Merlingen, 2007, Chandler, 2006, Baaz, 2005, Branch, 2004) Consequently, very little scholarly energy has been put in the study of the possibility that our involvement as such might be problematic, and not just the way we go about it.

By focusing on the problematics of inequality and homogeny, in a first decolonizing strategy, this study instead drew attention to the elements of violence and domination in contemporary ethical foreign policies, regardless of intention, and explored on that ground the salience of ethical retreat. The idea was to find different ways to understand the overall poor track-record of ethical foreign policies beyond issues of efficiency, coherence, capacity and political will. Homogeny and inequality were concretized through the analytical framework of Ethical Intervener Europe, an instrument or a lens to study the problematics of ethical foreign policy in more detail and over time. The framework presented a set of ideal-typical mechanisms - the inequality mechanism and intervener-centric mechanisms - to characterise and explain EU ethical foreign policy. 
The inequality mechanism described how next to the material inequality between the intervener and the receiver, e.g. the EU and Africa, another fundamental inequality is maintained through the ethical relationship. Similar to what Mahmood Mamdani (2010) calls a bifurcation of the world's peoples into those that are capable and those that are not, the inequality mechanism highlights how the receivers are perceived or presented as opposed to the interveners, be it malevolent vs. benevolent, lacking or incapable vs. capable and expert, to conceive, define and deliver a tailor-made well-being. Applied to the emerging ideals of 'African solutions for African problems' and local ownership in development discourse, the inequality lens allows for a debate on how far-reaching and genuinely transformative those new points of attention have been. While the ownership discourse may have spurred some changes in ethical foreign policy practices, so far it seems that the underlying assumption of hierarchised difference, i.e. inequality in the present, is maintained. It is rather an equality in the future, after a process of capacity building, which is being serviced in the recent development discourses on ownership. A right to self-management, rather than to self-determination.

The intervener-centric mechanisms intimated how the persistence of the perception of inequality or incapability is closely linked to the fact that the intervener, even though it finds its legitimacy in and is designed to contribute to the well-being of the receiver, is firmly at the centre of all ethical foreign policy. This self-centred altruism applies both to the occurrence (shall we intervene or not? free funds or not? sanction or not?) and the content (free market liberal democracy) of ethical foreign policy. A general and openended notion of well-being in such relation transforms into becoming the intervener and/or fitting into the reality of the intervener. Herein lies the element of homogeny in contemporary ethical foreign policy. The role and the control of the intervener is thus perpetuated in time and the non-participation of the receiving actors is structurally embedded in the ethical foreign policy.

Secondly, I looked for decolonizing alternatives to contemporary ethical foreign policy and explored the literature on autonomous recovery as developed by Jeremy Weinstein and the principles of the politics of difference as advocated by African and (African-)American radical and participative democracy scholars such as Iris Marion Young, Cornel West and Claude Ake. Autonomous recovery challenges the assumption of the innate salience of external assistance. Weinstein argues that autonomous recovery is more likely to result in long-term stable and peaceful government than aided recovery. The main reasons for that being that the lack of external support first of all forces the warring parties to turn to the population for resources and fighters for their cause, thus depending on them for legitimacy, both in war and in the following peacetime. Secondly, the absence of external support diminishes the likelihood of an infinite pool of resources, thus expediting the moment of war-fatigue. The second alternative explored how, against homogeny and intervener-centrism, a notion of democratic politics of difference, not based on nationality or ethnicity but on the degree to which policy affects someone, frees up space for receivers to enact their democratic right to build a society to their own vernacular image (Scott I999). 
In a third decolonizing strategy, I turned to the unique case of Somaliland, one of the few places in Africa that has seen a relative successful form of autonomous recovery after state collapse and civil conflict. Through 39 in depth interviews in the capital Hargeisa, Addis Ababa, Nairobi, London and Brussels, I looked for the self-appreciation of Somaliland academic, political and civil society elites of their peace-and statebuilding process and the role of the international community in this. This material allowed for a refinement and enrichment of my analytical framework on homogeny and inequality and the alternatives of autonomous recovery and politics of difference. One refinement pertained that homogeny and inequality are to a large extent internalized by the receivers, even in the case of Somaliland which had had a unique experience with self-determination.

\section{Further research}

In the book review in the thesis I put forward that ideally, the study of ethical foreign policy should a) have a profound analytical knowledge of all the current foreign policy actions projected in ethical terms, b) be reflexive in nature, critically assessing the power relations that define what is ethical or not as well as the role played by the powerful in the creation and perpetuation of the identified 'unethical' situations of the 'Others', and c) have the courage to distil from this a minimal yet timeless notion of a normative standard against which to evaluate contemporary international behaviour.

The decolonizing strategies in this study, enacted in the study of the viability of ethical retreat and the deconstruction of the problematics, extensively cover the two last points in the proposed ideal type ethical foreign policy agenda. With regard to the first one, it has to be said that more than anything, this project has been a study on how to study ethical foreign policy differently, rather than presenting extensive new empirical material or ground-breaking discoveries about ethical foreign policy realities on the ground. This is a clear opportunity for further research. The Ethical Intervener Europe framework can be applied more thoroughly on actual cases of EU or other western ethical foreign policies to meet the first standard of an intimate detailed and analytical knowledge of the existing policies that are being projected as ethical. What was done in this study by looking at the existing EU-Africa documents and the case of Somaliland, are in this respect merely timid introductions to a radically different systematic research on international ethical action. A decolonized analytical research agenda on ethical foreign policy requires what Merlingen refers to as the need for more micro-empirical analyses to thoroughly understand the workings of power in ethical foreign policy, such as in the concept of Normative Power Europe (Ian Manners) in EU studies. In the case of Somaliland, rather than limiting oneself to the self-appreciation of the Hargeisa elite on broad themes such as the peace- and statebuilding process spanning two decades, further research could envisage a genealogical approach, a detailed governmentality study of a specific EU programme or policy in light of the Ethical Intervener Europe analytical framework, drawing materials both from policy documents, policy outcomes on the ground, interviews with European policymakers and programme officers. Most importantly, for it to constitute a decolonizing strategy, it would be crucial that the self-appreciation of the peoples con- 
cerned is seen as a first indispensable step in the research design, upon which all the rest can be developed.

Having said that, in the west, one nevertheless faces the limits of decolonizing ethical foreign policy research. As reiterated in the conclusion of the last paper in this study, western-centricity is difficultly avoidable in a research designed to say something meaningful about western ethical foreign action. Giving voice to the people concerned is, as Spivak has extensively discussed, limited by all the elements that get lost in translation, due to language or the different power positions between 'subaltern' and western researcher. During my fieldwork in Somaliland it was visibly helpful that I was from African descent myself, nevertheless, the interviews were set against the background of western categories on state- and peacebuilding and my western understanding of reality. A decolonized western ethical foreign policy research agenda would greatly benefit from an ample and systematic participation of non-western researchers in the west and the nonwest.

Lastly, the consistent application of the decolonizing strategy to ethical foreign policy research led this study to the idea of ethical retreat. Further research in that area would logically lead us away from ethical foreign policy towards new avenues. In this research project we ended up looking at domestic radical democracy literature. It may well be that a future decolonised research agenda on ethical foreign policy must first of all linger a little while longer at the study of participative democracy, sovereignty and self-determination, before undertaking the micro-empirical governmentality study of ethical foreign policy. A genealogy of enactments and conceptualizations of e.g. self-determination in post-colonial places like the African American civil rights movements of last century or the concept of Agaciro ${ }^{2}$ in contemporary post-genocide Rwanda, are but few examples on how to further feed the existing R2P dominance in today's understanding of 'doing good' in the world. The most significant contribution of this study, apart from it decolonial framing of the argument, is that it has systematically, and hopefully convincingly, expanded the understanding of the problematics in the $\mathrm{R}_{2} \mathrm{P}$ doctrine beyond the realm of the instant (military) humanitarian interventions to all areas of western ethical involvement elsewhere. Ultimately, the conclusion can only be that even after all these years, the research journey seems to have only just started.

\section{References}

Arts, K. and Dickson, A., eds., (2004). EU development co-operation from model to symbol. Manchester: University Press.

Baaz, M., (2005). The paternalism of partnership. London: Zed Books. 
Branch, A., (2005). Winning the war, but losing the peace? The dilemma of SPLM/A civil administration and the tasks ahead. The Journal of Modern African Studies, 43 : I-20 Cambridge University Press.

Carbone, M., (2008). Mission impossible: The European Union and policy coherence for development. Journal of European Integration, 30(3), pp. 323-342.

Chandler, D., (2006). Empire in denial. London: Pluto Press.

Doty, R.L., (1996). Imperial Encounters. Minneapolis: University of Minnesota Press.

Fanon, F., I96I, (2008). Concerning Violence. London: Penguin Books Great Ideas.

Ferguson, J., (I990). The anti-politics machine. Minneapolis: University of Minnesota Press.

- (2007). Global shadows, Africa in the neo-liberal World Order. Durham: Duke University Press.

Henderson, E., (2007). Navigating the Muddy waters of the mainstream. The mystification of racism in International Relations. In Rich, W., African American perspectives on political science. Philadelphia: Temple University.

Jones, B., (2006). Decolonizing International Relations. Lanham: Rowman \& Littlefield.

Kapoor, I., (2008). The Post-Colonial Politics of Development. New York: Routledge.

Mamadani, M., (2010). Responsibility to protect or right to punish? Journal of Intervention and Statebuilding, $4(\mathrm{I}), \mathrm{pp} .53-67$.

Merlingen, M., (2007). Everything is dangerous: a critique of "normative power Europe". Security Dialogue, 38(4), pp. 435-453.

Muppidi, H., (2012). The colonial signs of International Relations. London: Hurst \& Co.

Paris, R. and Sisk, T., (eds.), (2009). The Dilemmas of Statebuilding. Confronting the contradictions of postwar peace operations. New York: Routledge.

Sabaratnam, M., (20II). IR in dialogue but can we change the subjects? A typology of Decolonising Strategies for the Study of World Politics. Millennium Journal of International Studies, 39:3, pp. 78I-803.

Said, E., (1978). Orientalism. London: Penguin.

Scott, D., (1999). Refashioning Futures: Criticism After Postcoloniality. Princeton: Princeton University Press.

Seth, S., (2013). Postcolonial theory and international relations: A critical introduction. New York: Routledge.

Smith, K. and Light, M., (200I). Ethics and foreign policy. Cambridge: University Press.

Vitalis, R., (2000). The Graceful and Generous Liberal Gesture: Making Racism Invisible in American International Relations. Millennium Journal of International Studies, 29:2, pp. 331-356. 